\title{
Når legelivet venter
}

«Livet som lege er travelt og rolig, lærerikt og kjedelig, skremmende og ren plankekjøring, koffeinkrevende og oppkvikkende!» responderte en kullkamerat da jeg samlet erfaringer fra våre første år som lege. Den siste forelesningen på medisinstudiet ved Norges teknisk-naturvitenskapelige universitet handler rett og slett om livet som lege.

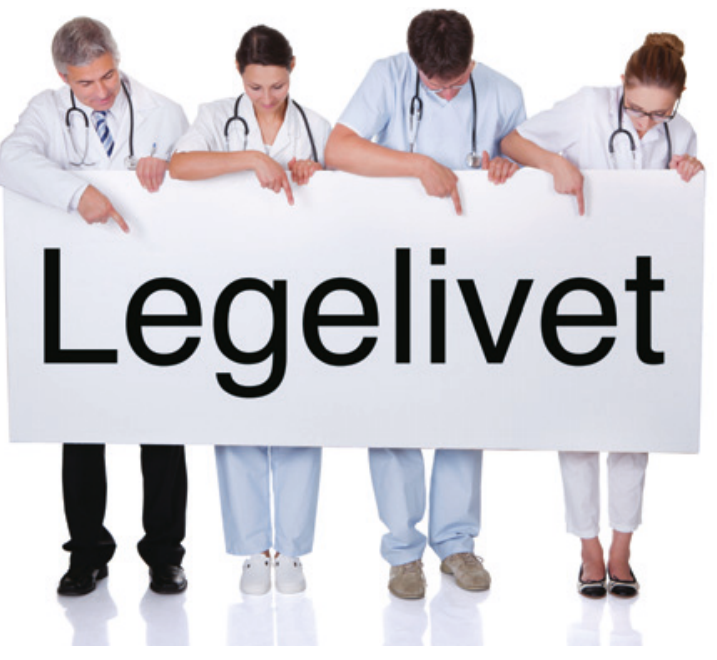

Illustrasjonsfoto Isttockphoto

I fem år har jeg årlig spurt mine 100 kullkamerater på e-post eller sosiale medier om hvilke råd de har til studentene som straks møter arbeidslivet. Min ikke-randomiserte, ikke-kontrollerte studie med høyst uklare endepunkter, basert på disse 500 legeårene, kan sammenfattes med at livet som lege er «altfor hektisk, men utrolig moro» og at «den utrolig spennende hverdagen veier opp for veldig mye av jobbinga».

Kanskje kan de gode rådene også komme til nytte hos flere av mine kommende kolleger?

Avskjedsforelesningen for avskjedskullet på medisinstudiet ved Norges teknisk naturvitenskapelige universitet heter Livet som lege. Forelesningen ble til i 2007 på forespørsel fra studentene, som ønsket en avskjedsforelesning som bandt studiet sammen, og rettet blikket fremover. Linn Getz etablerte forelesningen sammen med Steinar Westin og Niels Bentzen, og fra 2009 har jeg deltatt sammen med dem - først som purung turnuslege, nå som forholdsvis uerfaren assistentlege. Jeg ønsket å bringe til torgs erfaringer vi som unge leger gjør oss de første årene, og ut fra dem trekke frem gode råd til våre kommende kolleger.

\section{Senk skuldrene}

Hovedbudskapet til avskjedskullet, våre nye turnusleger, er å senke skuldrene og brette opp ermene - og glede seg til tiden som kommer. Mine kullkamerater har skrevet til meg om tøffe erfaringer, men først og fremst om mange positive erfaringer: pasientmøter med mestringsfølelse, følelse av å utgjøre en forskjell, med resultat takknemlige pårørende og takknemlige pasienter. I denne arbeidshverdagen understreker mange at telefonen til bakvakten skal være lett å plukke opp: «Som turnuslege er man ny i jobben: Ingen forventer at du skal kunne alt - og det er alltid noen bak deg.»

Med en medbrakt erkjennelse om at fagfeltet er uendelig stort, skriver en at det «derfor er smart å være ydmyk i forhold til egne kunnskaper». Konklusjonen blir likevel at «balansegangen mellom å stole på seg selv kontra å spørre som hjelp, er noe man bare må finne ut av selv gjennom egne erfaringer». Det studietiden kanskje ikke lærer oss så mye om, er det flerfaglige og tverrfaglige arbeidet, og hvordan legerollen er en av flere roller i et kollegium. «Jeg hadde ikke tenkt så mye på at man blir en del av et kollegium med en rekke yrkesgrupper involvert, og vet nå at utbyttet både i form av læring og trivsel er avhengig av hvordan man investerer i det arbeidsmiljøet.»

\section{Vi er heldige}

«Det beste med legelivet er alle skjebnene du møter. Det er innblikket du får i livet, og i døden. Jeg tror vi blir kloke av å jobbe som leger, nettopp fordi vi møter mennesker og deres historier hele tiden», responderte en annen kullkamerat. Hun beskriver godt noe flere kjenner på - at vi er heldige som får møte og komme nær mennesker $i$ alle livets faser, eller kort og godt at «det beste med livet som lege er at man møter masse folk!» Til våre kommende kolleger vil jeg sammen med flere likevel under- streke at «livet utenom er selve livet!», og «for å være en god lege, må du ha et godt sidespor».

Å sette grenser mellom privatlivet og legelivet kan være utfordrende - men ikke desto mindre viktig. Vi har et langt yrkesliv foran oss og er best rustet til det som hele mennesker. «Pasientene dine er avhengig av at du tar vare på deg selv, for at du skal klare å ta godt vare på dem.» Og rådet gjelder enten du er den som «setter pris på adrenalinrushet når den alvorlig syke pasienten kommer inn døra» eller den som «velger seg et ikke-akademisk legeliv i periferien».

Forelesningen Livet som lege i Trondheim er et verdig punktum i en seks år lang forelesningsserie. Selv har jeg årlig fått muligheten til selvransakelse i mitt eget legeliv, før jeg sent $i$ april har delt erfaringer med avskjedskullet og fått korsang, kake, bobler og alvor tilbake. Jeg gleder meg til å møte våre nye turnusleger proppfulle av kunnskaper, forventningsfulle til yrket de har valgt, men bevisste på at «de største seirene og nederlagene skjer på hjemmebane».

Tidsskriftet har også snakket med både blogger Maria Serafia Fjellstad og studenter som deltok på hennes forelesning. Hør podkast: http://soundcloud.com/tidsskriftet/ podkast-n-r-legelivet-venter

Kommentarer til og diskusjoner om innlegget finner du på blogg.tidsskriftet.no 